\title{
Chapter 11 \\ Changes in Occupational Structure and Residential Segregation in Tokyo
}

\author{
Masaya Uesugi
}

\begin{abstract}
Similar to other industrialized countries, Japan has experienced a growth in income inequality since the 1980s. Furthermore, in the past few decades, Tokyo has come to adopt a more liberalist position for not only welfare and housing policy of the state but also to urban policy. This chapter examines the changes in sociospatial inequality in Tokyo from 2000 to 2015. During this period, segregation indices confirm some level of residential separation between the top and bottom occupational groups, and segregation is fairly stable over time. This suggests that certain factors counteract the increase of residential segregation. A comparison between the Tokyo Metropolitan Region and the core city reveals that the core city amplifies spatial inequality. In contrast to the limited change in the city-wide levels of segregation, the changes in the residential patterns show that people with high occupational status tend to concentrate around the main railway station in suburban areas in the region and inside the core city, especially adjacent to the central neighborhoods.
\end{abstract}

Keywords Occupational structure $\cdot$ Residential segregation $\cdot$ Neighborhood • Tokyo

\subsection{Introduction}

Since the 1960s, a robust middle class has developed along with the growth of the economy in Japan. Around 1970, Japan belonged to the group of the lowest economic inequality among the OECD countries, along with the Nordic countries (Sawyer 1976). However, the Gini coefficient and the relative poverty rate increased and became higher than the OECD average in the 2000s, which evoked public and political discourse on various forms of inequality (Chiavacci and Hommerich 2017).

An important manifestation of inequality from a geographical perspective is residential segregation. Recent international comparative studies suggest that levels of residential segregation depend not only on levels of economic inequality but also

\footnotetext{
M. Uesugi $(\bowtie)$

Fukuoka Institute of Technology, Fukuoka, Japan

e-mail: uesugi@fit.ac.jp
} 
on contextual factors such as welfare, housing regimes, and political and institutional environments (Tammaru et al. 2016). Tokyo is not only Japan's center of economy, politics, and culture but also one of the most global cities with New York and London, as highlighted by Sassen (1991), whose examination of social polarization and its impact on social geography has attracted abundant interest from scholars. In the central part of Tokyo (Tokyo City area consists of 23 special wards; hereinafter, referred to as City), a distinct pattern of socio-economic segregation has been identified for several decades: white-collar workers are concentrated in the upland area (Yamanote) and spread from the center to the west of the city, and the blue-collar workers live principally in the lowland downtown area (Shitamachi) in the east (Kurasawa and Asakawa 2004). In the early 2000s in particular, managerial workers tended to concentrate in the city center (Wakabayashi and Koizumi 2018). On the other hand, although acknowledging such a contrast in general, Fujita and Hill (2012) and Wissink and Hazelzet (2012), who investigated the proportion of different social classes at the neighborhood level, suggested that neighborhoods in Tokyo are socially mixed.

Another definition of the Tokyo area is the Tokyo Metropolitan Region (hereinafter, referred to as Region), which includes suburban areas of neighboring municipalities. Studies at the level of municipalities found that the distribution of high-income residents shifted from the suburbs to the city from the 1980s to the 2000s (Jacobs 2012; Toyoda 2007). They also stress that residential segregation has increased with elevated income levels in Yamanote and the city center, and decreased income levels in Shitamachi and the peripheral area.

We must ask ourselves if the level of residential segregation in Tokyo is greater than in cities of other countries. Fielding (2004) demonstrated that although there is a certain degree of socio-economic segregation at neighborhood level in Japan, it is lower than that of a British city. As reasons for this, he refers to the smaller income disparity in Japan compared to Great Britain. In addition, Fujita and Hill (2012) argued that several factors, including a centralized tax system and public housing policy, prevent income inequality from leading to class-based segregation in Tokyo. Jacobs $(2005,2012)$ confirmed that residential segregation in Tokyo was less than in the larger US metropolitan areas, despite the fact that income disparity between municipalities expanded in the Tokyo metropolitan area after the 1980s. He emphasizes the significance of severe restrictions on immigration (the number of migrant workers is very low in Tokyo) and the government policy to prevent socio-economic fragmentation of municipalities in Japan.

Previous studies on segregation in Tokyo covered its changes until the mid-2000s, but since the late 2000s, Tokyo has experienced some major socio-economic changes, such as the global financial crisis triggered by the bankruptcy of Lehman Brothers in 2008, the M9.0 Great East Japan earthquake ${ }^{1}$ of 2011, and unprecedented monetary easing by the central bank of Japan from 2013. Income inequality, the welfare system, and the housing system are also changing. In this chapter, based on these contextual changes, we elucidate the process of social-spatial change in Tokyo from 2000 to 
2015. In addition, this study will contribute to the field of socio-economic segregation by emphasizing the relationship between city and suburb based on two different definitions of Tokyo (Region and City). ${ }^{2}$

\subsection{Context}

\subsubsection{Income Inequality}

Since the 1980s, income inequality has been increasing in many countries (OECD 2015). During this time, income inequality has also been on the rise in Japan, albeit slightly, as indicated by the Gini coefficients of equivalent disposable income. However, the size of the coefficient varies somewhat depending on which data are used. OECD data indicate the coefficient increased from 0.30 in 1985 to 0.34 in 2000 and decreased slightly to 0.32 in 2003. After that, the coefficient rose to 0.34 again in 2009. Nevertheless, the Gini coefficient of 0.33 in 2013 remained higher than the OECD average of 0.32 (OECD 2015). Japan's Gini coefficient, based on the National Survey of Family Income and Expenditure provided by the Ministry of Internal Affairs and Communications, is smaller in size, but indicates a similar trend: it increased from 0.25 in 1984 to 0.28 in 2009 and remained flat in 2014.

The publication of statistics indicating growing income inequality in Japan from the 1980s until the 1990s provoked strong reactions; for example, Tachibanaki's (2005) assertion that Japan is no longer a middle-class society. However, the reasons for these changes are not universally agreed upon, with some also pointing a finger at the aging population and the shrinking size of households (Ohtake 2008). Nevertheless, Shikata (2013) argued that income inequality began to increase within age groups after 2000 and that this was due to factors such as the increase in irregular employment in all age groups, rather than demographic causes. In fact, since 2007, over one-third of all workers have been irregular workers, and their number has doubled since the 1990s (MHLW 2013).

\subsubsection{Welfare System}

There is no consensus regarding which of the three main types of welfare regimes of Esping-Andersen (1990) corresponds to that of current Japan. As described below, the characteristics of the Japanese welfare state can be aligned with multiple welfare regimes (MHLW 2012). First, policy in Japan has emphasized employment security, protecting employment through measures such as minimizing layoffs by companies and public work projects. Japan also guarantees a pension, health insurance, and services to all its citizens. As a result, the country has maintained a low unemployment rate on par with that of countries with social democratic welfare regimes. Conversely, 
Japan's system includes characteristics of a conservative welfare regime; for example, the generous social security benefits for the elderly and its strong emphasis on the family. However, the system also contains elements peculiar to a liberal welfare regime. Social security expenditure, as a whole, is relatively limited and medical benefits (universal health care) in Japan are comparable to those in the US and the UK as a share of GDP.

Since the 1990s, however, increasing globalization of the economy and intensified international competition among companies as a result of the government's liberal policies, have fostered an increase in the number of irregular workers, who can be utilized flexibly and cheaply. Widespread layoffs of temporary workers became a social problem during the 2008 economic crisis, highlighting the limited institutional support available to those who have left the labor market. As social security expenditure balloons to keep pace with the aging population, calls for fiscal reform have increased and benefits, such as medical benefits and pensions, are being reduced. Consequently, for example, individual pensions have become smaller for nearly 20 years.

\subsubsection{Housing System}

Japan's post-WWII housing policy was drawn up with the aim of improving deficient housing and ameliorating housing shortages. Under the principle that every family should have its own home, the core of the housing policy was that such housing systems should ultimately allow individuals to acquire their own housing via the market, principally by providing support in the form of mortgage loans. The government provided the middle-income households with long-term and low-interest loans to buy their own home through the Government Housing Loan Corporation. In addition to that, the government encouraged housing ownership with a tax reduction.

The population living in urban areas increased rapidly in Japan during the period of high economic growth from the 1950 s to the 1960s. As the economy grew, residential developments in the suburbs, featuring mainly detached single-family homes, served to house the rapidly expanding middle class. During the 1980s economic bubble, soaring land prices further accelerated the move to the suburbs. An overview of the Tokyo metropolitan area suggests that homeownership developed chiefly in the suburbs. In the city center and adjacent areas, where land prices were high, affordable land and housing were in short supply. Consequently, homeownership rates limped behind those observed in the suburbs (Takagi 2012).

Therefore, Tokyo, to this day, has a relatively small stock of public housing, including housing aimed at the middle-income bracket, and the percentage of people who own their houses is almost the same as the percentage of people using the private rental market. In spite of the weak support for the private rental market and the absence of rent regulation, the proportion of private rental housing tends to be high in urban areas. On the contrary, public housing provided by local governments has an income ceiling for tenants and the rents are regulated. The census revealed 
Table 11.1 The number of households by housing tenure, 2000-2015

\begin{tabular}{|c|c|c|c|c|c|}
\hline & & Owned houses & $\begin{array}{l}\text { Private rented } \\
\text { houses }\end{array}$ & Public rented houses & Others \\
\hline \multirow[t]{4}{*}{ Region } & 2000 & $6,957,839(54 \%)$ & $\begin{array}{l}4,247,686 \\
(33 \%)\end{array}$ & $928,973(7 \%)$ & $780,023(6 \%)$ \\
\hline & 2005 & $7,878,778(57 \%)$ & $\begin{array}{l}4,418,882 \\
(32 \%)\end{array}$ & $957,324(7 \%)$ & $671,051(5 \%)$ \\
\hline & 2010 & $8,604,807(56 \%)$ & $\begin{array}{l}5,063,638 \\
(33 \%)\end{array}$ & $957,222(6 \%)$ & $682,040(4 \%)$ \\
\hline & 2015 & $9,151,634(57 \%)$ & $\begin{array}{l}5,328,063 \\
(33 \%)\end{array}$ & $903,839(6 \%)$ & $584,339(4 \%)$ \\
\hline \multirow[t]{4}{*}{ City } & 2000 & $1,535,209(42 \%)$ & $\begin{array}{l}1,552,984 \\
(43 \%)\end{array}$ & $308,846(8 \%)$ & $255,952(7 \%)$ \\
\hline & 2005 & $1,802,545(46 \%)$ & $\begin{array}{l}1,594,717 \\
(41 \%)\end{array}$ & $317,194(8 \%)$ & $222,169(6 \%)$ \\
\hline & 2010 & $1,974,012(44 \%)$ & $\begin{array}{l}1,928,585 \\
(43 \%)\end{array}$ & $320,316(7 \%)$ & $244,417(5 \%)$ \\
\hline & 2015 & $2,131,735(45 \%)$ & $\begin{array}{l}2,060,441 \\
(44 \%)\end{array}$ & $308,212(7 \%)$ & $222,845(5 \%)$ \\
\hline
\end{tabular}

Source Population census

that in $2010,44 \%$ of households in the City-owned their own houses, while those in private rental housing comprised $43 \%$, and those in public housing $7 \%$, indicating that little has changed since 2000 (Table 11.1).

However, this system has been gradually crumbling since the mid-1990s. The 5-year housing plans, which were implemented by the goverment from 1961 during a period of high economic growth in order to supply sufficient housing stock, took a more market-oriented turn in the 2000s. Another development was the Basic Act for Housing, enacted in 2006 amid trends such as population decrease, a declining birthrate, and an aging population. This law aims to improve the environment of the housing market by, for example, ensuring a stable supply of housing loans and implementing tax-related measures.

\subsubsection{Urban Policy}

In Tokyo, Urban Regeneration was launched by the state as a policy to reverse the long-term recession that followed the collapse of the bubble economy in 1991 and that dragged on throughout the 1990s. The "emergency development areas for urban regeneration" were designated principally in the three central wards, with the aim of attracting private investments in urban development. By the first half of the 2000s, these areas experienced a marked increase in the supply of office buildings and condominiums (Ueno 2008). During the same period, deregulation of urban 
planning encouraged private investments in urban redevelopment. Deregulation, as part of urban policy, is commonly considered to be an important factor behind social and spatial changes (van Kempen 2007). In fact, although some urban redevelopment projects are implemented jointly by private developers and public sectors in Tokyo, most are undertaken by the private sector, mainly by large Japanese corporations, backed by the Tokyo Metropolitan Government. This has played a large role in urban restructuring in Tokyo (Waley 2007), mainly taking place in the center of the city and by Tokyo bay.

The above-mentioned developments changed the urban landscape and the spatial structure of Tokyo (Waley 2013). Lützeler (2008) suggested that this kind of middle class-oriented development of a city center risks triggering class-selective migration and increases the overall level of residential segregation. Hirayama (2005) highlighted urban renewal policy implemented from the late 1990s to the early 2000s stimulated the housing market, which resulted in the simultaneous emergence of "hot spots" in the city center and "cold spots" in the surrounding areas as a noticeable example of residential inequality. The "hot spots" were characterized as clusters of condominium skyscrapers, such as Roppongi, Shinagawa, and Toyosu districts (see Fig. 11.2). As one of those urban development projects-Roppongi Hills that consists of a mix of office, commercial, and residential functions with 720 thousand $\mathrm{m}^{2}$ of floor space implemented by a private developer-became a symbol of those high-end neighborhoods of Tokyo. In Shinagawa District near Tokyo bay, several private developers built high-rise buildings for offices and residences, using the site of Japan National Railway. The Japanese National Railway, a former governmentowned company, has been privatized in 1987 and disposed of some railway yards that were no longer used in order to reduce the debt. High-rise condominiums have also been on the rise in the waterfront area around Toyosu. Conversely, the market was stagnant in the "cold spots." In the early 2000s, some cities located in the suburban area, such as Sayama City and Konan Ward in Yokohama City, had lost their population despite their advantage of access to the city center.

\subsection{Data and Methods}

In this research, we used census data from 2000, 2005, 2010, and 2015. Tokyo is defined in two ways: Region and City. The Region is the functional urban area (FUA) and comprises Tokyo and certain areas in Kanagawa, Chiba, Saitama, Ibaraki, Yamanashi, and Tochigi prefectures, as defined by the OECD (2013). The City is the central area of the Region and consists of 23 special wards. As of 2015, the population of the City is 9.3 million and the population of the Region is 35.7 million, accounting for approximately one-quarter of the entire Japanese population. In the census, the number of employed persons by occupation is available at cho district level (hereinafter, referred to as neighborhood level), which is the smallest census tract. The average number of residents of this unit is approximately 1,700 for the Region and approximately 3,000 for the City. 
However, there are two problems with this data. First, since the boundaries of some neighborhoods were changed between 2000 and 2015, in this study, we re-aggregated the census data from 2010 and before according to the latest 2015 census boundaries. Second, the Japan Standard Occupational Classification, which does not necessarily correspond to the International Standard Occupational Classification (ISCO), was revised in 2009 (Ministry of Internal Affairs and Communications 2009). Some major groups of blue-collar workers were abolished and restructured to new groups. Moreover, classifications of some sub-major groups were revised, although the label did not necessarily change. In this study, major occupational groups are assigned to three socio-economic groups as follows: the top group consists of administrative and managerial workers and professional and technical workers; the middle group of clerical workers, sales workers, security workers, and service workers; and the bottom group of transport and communication workers and production process and related workers (manufacturing process workers, construction and mining workers, and carrying, cleaning, packaging, and related workers in 2010 and 2015).

We first examined the polarization thesis of Sassen (1991), starting from the 2000s, based on the changes in occupational structure. Subsequently, we measured residential segregation between the top and bottom occupational categories using the dissimilarity index (DI) (Duncan and Duncan 1955), which is a traditional indicator of residential segregation between two specific groups. Next, from a geographical point of view, we used three kinds of maps to verify the spatial patterns of residential segregation: concentration of the top occupational group, location quotient (LQ) for the top and bottom occupational groups, and classification of neighborhoods by socio-economic composition. First, the areas where the top group are concentrated are identified and sorted in a descending order based on the number of people in the top group. Neighborhoods including a cumulative population of one-fifth of the top group are labeled Q1, neighborhoods that contain the next one-fifth population in the top group are labeled Q2, and so on. If the number of Q1 neighborhoods is small, it means that top occupational groups are residentially concentrated only into a few neighborhoods.

Second, the spatial distribution of the LQ at both ends of the occupational hierarchy or top and bottom occupational groups is explored. LQ or the ratio of a certain occupation group in each neighborhood divided by the ratio of the same occupation group occupying the whole area is a well-known method for representing the spatial distribution of socio-economic segregation (Tammaru et al. 2016). When the LQ ratio for a certain group is greater than one, the group is over-represented in the neighborhood.

Finally, we investigated the within-neighborhood socio-economic intermixing from the spatial distribution of neighborhood classifications by socio-economic composition. According to the classification based on the proportion of the three socio-economic groups of Marcińczak et al. (2015), all neighborhoods fall into seven types: high socio-economic status (SES) neighborhoods, middle to high SES neighborhoods, mixed neighborhoods, middle SES neighborhoods, low to middle SES neighborhoods, low SES neighborhoods, and polarized neighborhoods. 


\subsection{Occupational Structure}

Sassen (1991) highlights that global cities have taken on a new role of strengthening and controlling global networks since the 1970s. In Tokyo, however, although globalization and de-industrialization have progressed, clear social polarization has not been observed. Machimura (1994) and Sonobe (2001) suggested that there were some signs of polarization in the 1980 s because both the number of professional/technical workers and the number of labor workers increased, although the number of intermediate workers did not decrease. Nevertheless, subsequent development, including the impact of the collapse of the bubble economy in the 1990s, has not been investigated sufficiently.

Figure 11.1 shows changes in the occupational structure after 2000 for the Region and the City. Although it should be noted that the occupational classification was revised between 2005 and 2010, the occupational composition in the Region and the City has remained stable over time. In both the Region and the City, the proportion of professional and technical workers has been increasing and the proportion of production process and related workers has been decreasing. At the same time, administrative and managerial workers constitute only a small percentage of the population, which, to some extent, has been declining in the 2000s. In the recession following, the bursting of the bubble in the early 1990s, many industries promoted the reduction of managerial and administrative positions by corporate restructuring. There was also an increase in business closure amongst small and medium enterprises. Thus, these processes suggested professionalization (Hamnett 1994) rather than polarization. Additionally, this tendency constantly continued until 2015, despite changes in socio-economic circumstances, such as the financial crisis of 2008 and the great earthquake of 2011.

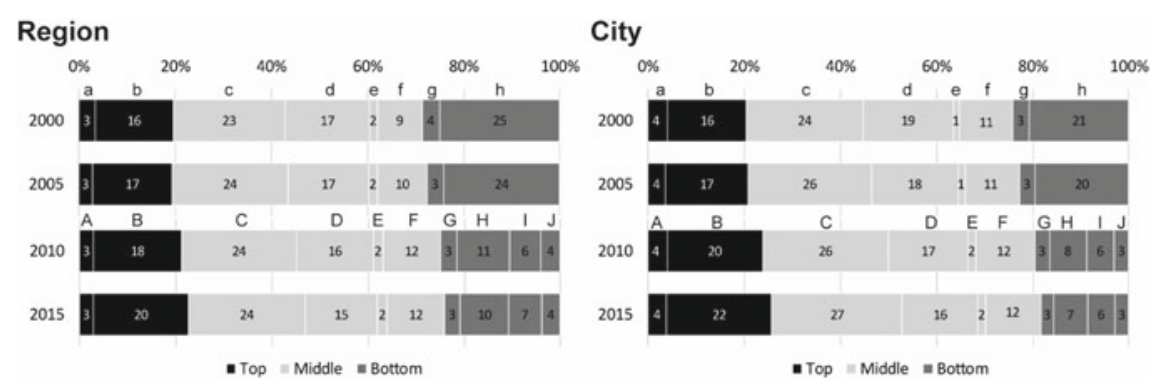

Fig. 11.1 Occupational structure in the Region and the City, 2000-2015. Notes Agriculture, forestry, and fishery workers and workers not classifiable by occupation are not included. 2000 and 2005: (a) Administrative and managerial, (b) Professional and technical, (c) Clerical, (d) Sales, (e) Security, (f) Service, (g) Transport and communication, (h) Production process and related. 2010 and 2015: (A) Administrative and managerial, (B) Professional and technical, (C) Clerical, (D) Sales, (E) Security, (F) Service, (G) Transport and machine operation, (H) Manufacturing process, (I) Construction and mining, (J) Carrying, cleaning, packaging, and related 


\subsection{Residential Segregation}

We used the DI to identify the extent to which the top and bottom socio-economic groups are residentially separated in the Region and in the City. The DI values range from 0 to 1, with a higher value representing greater levels of segregation. Table 11.2 shows the changes in the DI in both the Region and City between 2000 and 2015. The DI for the City is greater than that for the Region. Interestingly, Musterd and van Gent (2016) found a higher level of segregation for the metropolitan region than for the municipality of Amsterdam. For Tokyo, it seems the City amplifies residential inequality through the unique urban policies rather than serving as a "melting pot." In the Region, the DI has been stable, ranging from 0.26 in 2000 to 0.28 in 2005. Similarly, in the City, the DI has stayed almost unchanged at around 0.30. All in all, the range of change for both scales for the 15-year study period is quite small. Considering the limited change in the Gini coefficient, residential segregation might reflect the stability of income inequality rather than the change in occupational structure.

Table 11.2 Dissimilarity index (multiplied by 100) in the Region and the City, 2000-2015

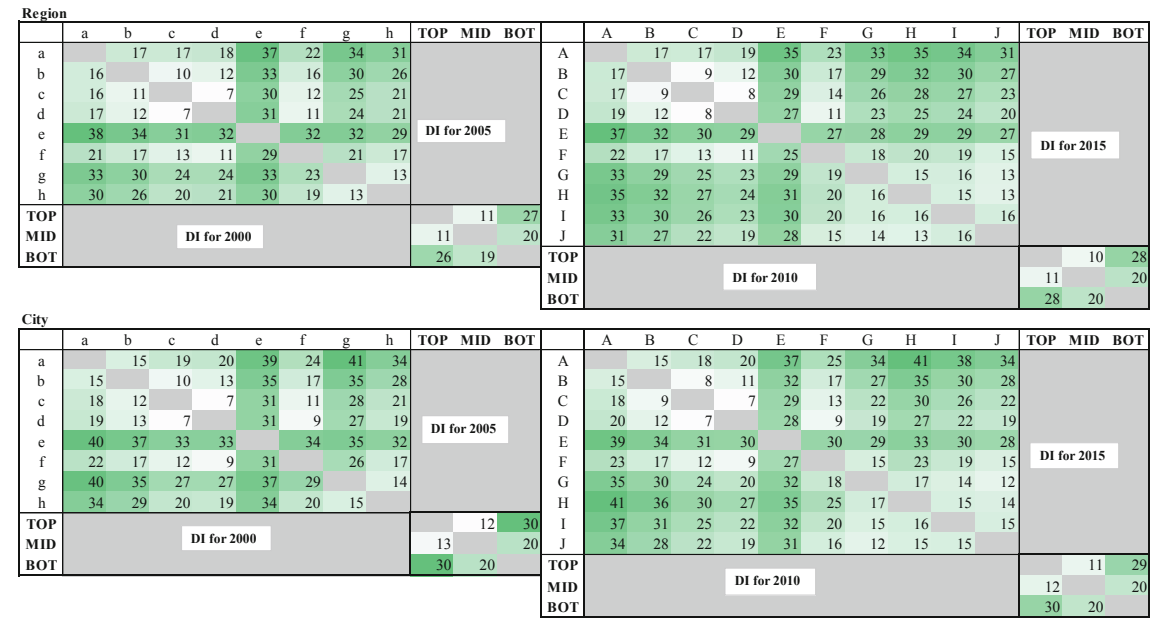

2000 and 2005: (a) Administrative and managerial, (b) Professional and technical, (c) Clerical, (d) Sales, (e) Security, (f) Service, (g) Transport and communication, (h) Production process and related. 2010 and 2015: (A) Administrative and managerial, (B) Professional and technical, (C) Clerical, (D) Sales, (E) Security, (F) Service, (G) Transport and machine operation, (H) Manufacturing process, (I) Construction and mining, (J) Carrying, cleaning, packaging, and related 


\subsection{Spatial Distribution of Occupational Groups}

\subsubsection{Concentration of the Top Occupational Groups}

Figure 11.2 illustrates the geographical distribution of the top occupational group in 2000 and 2010. The two main findings are as follows: first, top occupational groups are concentrated in the City, particularly in the central and western areas; and second, small clusters are formed along the railroads, in particular around some specific stations in the suburbs. It seems that the top occupational groups prefer to live around the railway station and commute to the city center by rail. Since 2000, there has been no major change and spatial patterns as of 2000 have been maintained throughout the 10-year study period. However, there is little change in the number of neighborhoods in Q1 inside the City-Q1 neighborhoods near the southern part of the City center increased and those around the western area decreased from 2000 to 2010, resulting in the growth of concentration for the top occupational group in

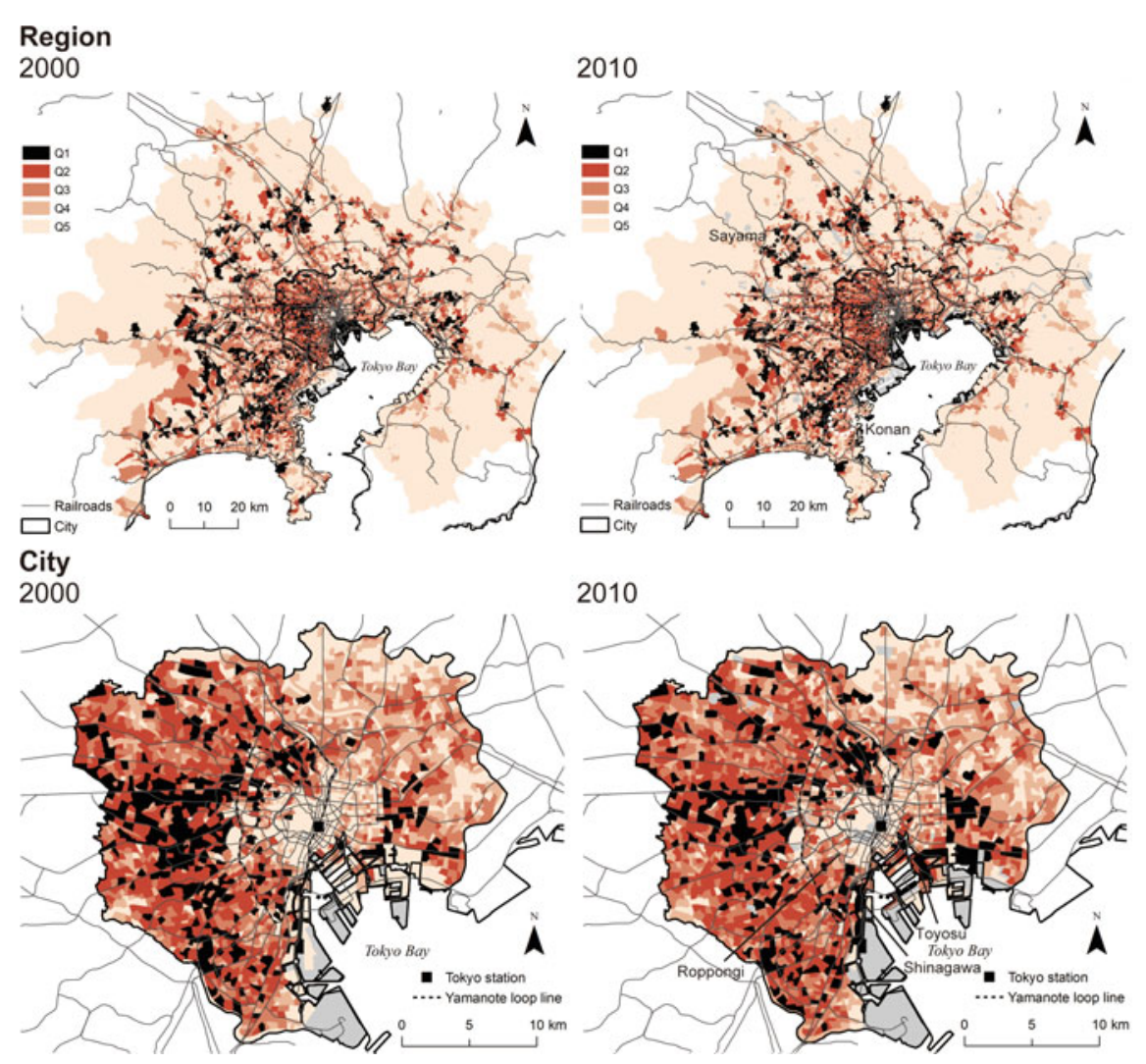

Fig. 11.2 Location of the top occupational group in 2000 and 2010 
the central districts of Tokyo. This demographic change is partly associated with gentrification that accompanied the upward shift in the socio-economic structure of residents. For instance, more and more wholesale shops and factories have been replaced by condominiums in such districts as Nihonbashi, Tsukishima, and Minato (Fujitsuka 2017). These districts are located within 2 or $3 \mathrm{~km}$ southeast of the business district surrounding Tokyo station.

\subsubsection{Location Quotient for the Top and Bottom Occupational Groups}

Figure 11.3 shows the LQ for the top and bottom occupational groups in 2000 and $2010 .^{3}$ In terms of the residential location of the top occupational group, in line with the findings of the previous section, there were several clusters in the Region, including in the center of the City. The residential patterns based on the concentric structure around the city center and railroad network have remained robust over time. Within the City as well, the top occupational group was concentrated in the city center. Neighborhoods with a high LQ prevailed in the center and became geographically agglomerated, especially inside the southern half of the Yamanote loop line. On the other hand, neighborhoods with a high LQ for the bottom occupational group spread to the suburbs, to the periphery of the Region, avoiding areas along the railroad lines. These sorts of low socio-economic neighborhoods are growing where the proportion of the bottom occupational group was already above average and the concentration continues to increase.

\subsubsection{Classification of Neighborhoods by Socio-economic Composition}

Figure 11.4 presents the geographical distribution of seven neighborhood types based on socio-economic composition. As confirmed in the previous section, high SES and high-middle SES neighborhoods are spreading from the center of the City to the west side and are scattered along the railroad toward the suburbs. Low SES and lowmiddle SES neighborhoods are distributed to the peripheral area. In the Region as a whole, there has been a remarkable growth of high-middle SES neighborhoods since 2000. Thus, while the absolute number of people in the bottom occupational group is decreasing, they are being pushed to peripheral areas of the Tokyo metropolitan area. In the City, the high SES and high-middle SES neighborhoods filled the inside of the Yamanote loop line to the west part of the City, including Roppongi, Shinagawa, and Toyosu districts. Additionally, as mentioned above, gentrification is generally considered to have occurred from the southern part of the city center to the east side. Although it is not shown on this map, the spatial patterns of 2010 are almost maintained in 2015. 


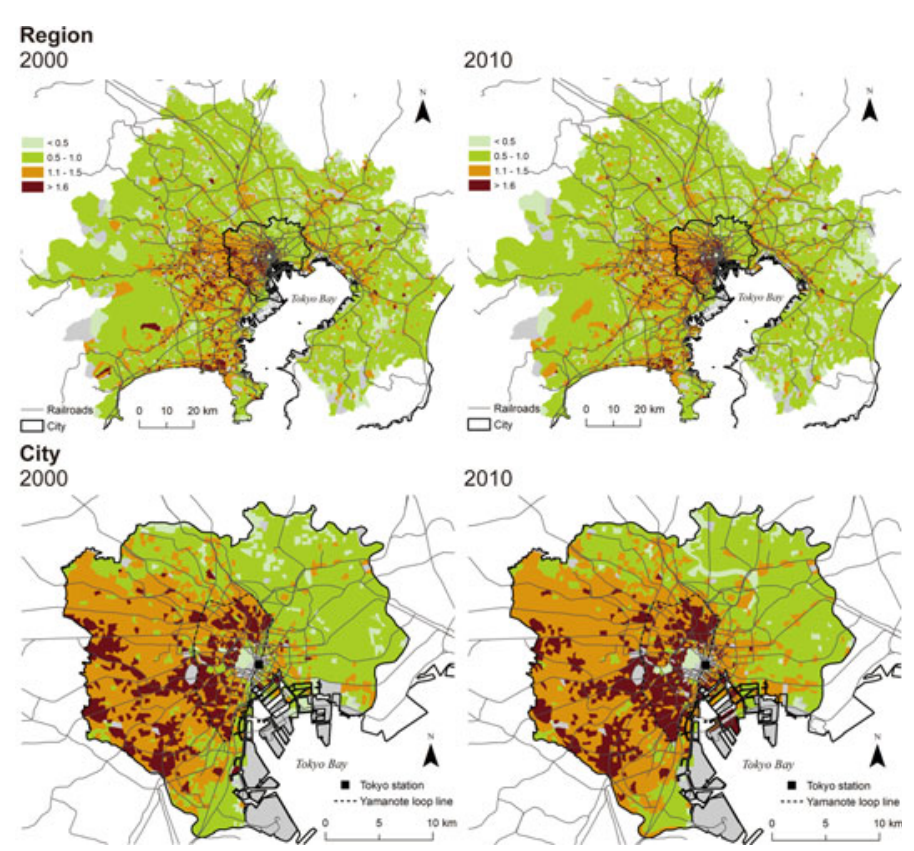

(a) The top occupational group

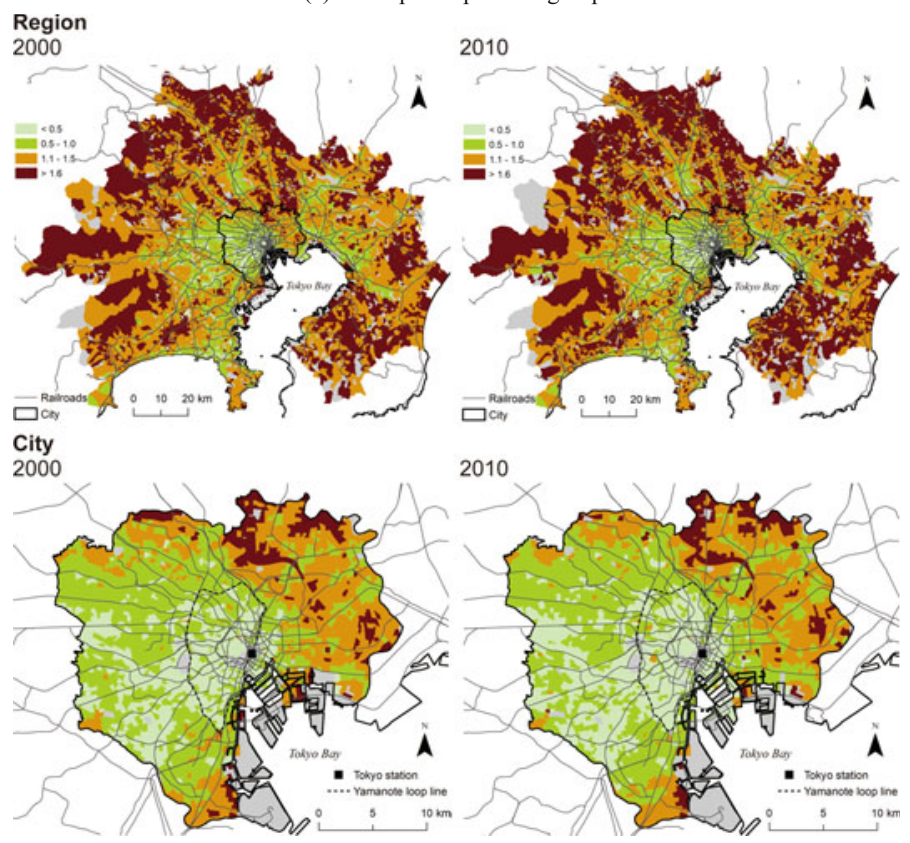

(b) The bottom occupational group

Fig. 11.3 Location quotient for the top and bottom occupational groups in 2000 and 2010 


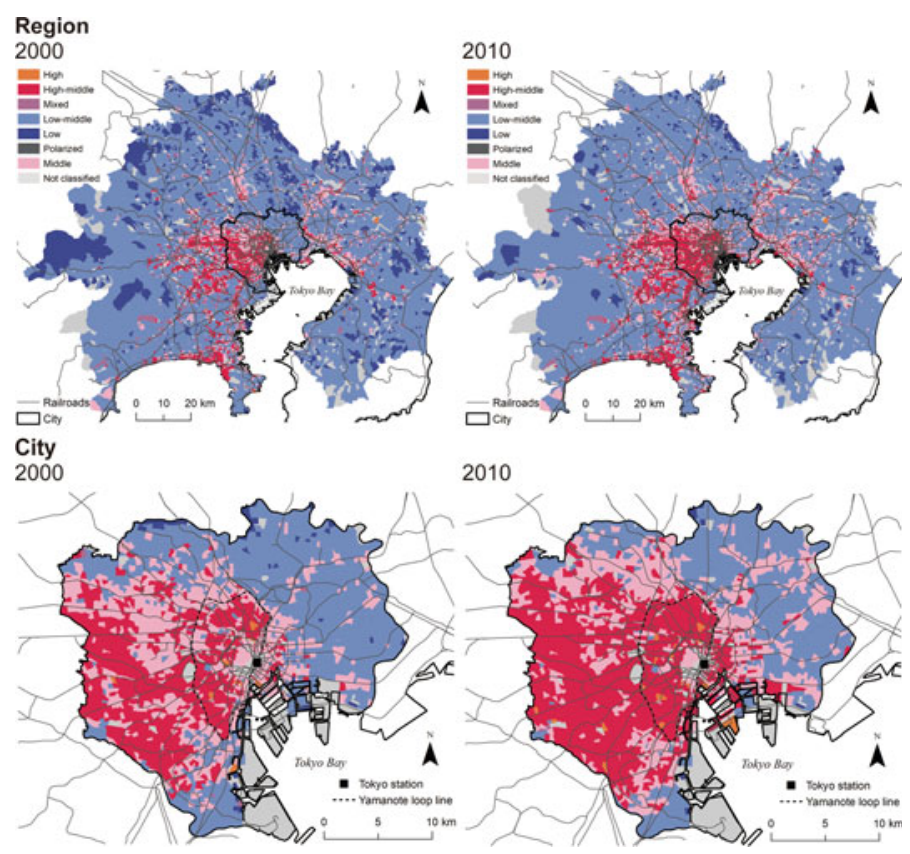

Fig. 11.4 Classification of neighborhoods by socio-economic composition in 2000 and 2010

\subsection{Discussion and Conclusions}

The results of the analysis of this chapter can be summarized as follows: A slight increase in income inequality that began in the 1980s continued apace during the early 2000s, spurred by the introduction of liberal welfare and housing policies. However, the trend somewhat reversed itself during and after the latter half of the 2000s, when the global financial crisis and the great earthquake occurred. Because the most recent data used in this study were from 2015, they may not fully reflect the impact of the large-scale monetary easing that Japan's central bank began in 2013. Nevertheless, the examination of the occupational structure in the Region and the City indicated that the social polarization thesis is not necessarily supported. The results of this research rather suggest that the occupational structure has been stable and a trend toward professionalization has occurred.

From a geographical perspective as well, the overall levels of residential segregation observed in Tokyo are very stable, with no sudden changes. One characteristic of metropolitan areas in Japan is that trains are the preferred mode of transport for people commuting to school and work, regardless of social class. This tendency is particularly strong among high-income people, as supported by the fact that the area with higher per-capita income is associated with shorter commuting time in the Tokyo metropolitan area (Yoshida and Endo 1999). Beginning from the period of high economic growth in the 1950s, urban areas have expanded along railway 
lines, resulting in the development of city structures defined by railway lines and concentric circles expanding from the city center into the Region. Nevertheless, the constant level of residential segregation in the Region and the City during the 2000s suggests that small variations in residential segregation may reflect limited changes in income inequality and not so much the changes in occupational structure. During this period, Tokyo follows several trends identified by previous research (Koizumi and Wakabayashi 2015): for example, people in the high socio-economic group became concentrated even further in established, convenient, high-density areas. Trends such as gentrification may have an important influence on residential moves through exclusionary effects, which would be in line with the gentrification of the top and suburbanization of the bottom occupational groups observed in Western cities (Hochstenbach and Musterd 2018).

These results suggest that in Tokyo, social polarization and residential segregation did not increase as predicted by the global city thesis. Some studies have identified the strength of government control as the cause for this observation (Jacobs 2005; Waley 2013). Although, and as mentioned above, government regulations relevant to the labor market, the housing market, and urban policy are evolving in a more liberal direction, there has not been a complete turn toward neo-liberalism (Waley 2013). Strict regulations towards immigration still play an important role since in many global cities immigrants from low-wage countries often take on low-skilled, low-wage jobs in growing personal and production services. This makes an influx of immigrants: one of the main causes of social polarization in many other global cities (Sassen 1991). The census indicates that foreigners comprised $2.1 \%$ of the total population of the Region in Tokyo in 2015, which is very low compared to other countries. Even within the City, the $2.1 \%$ figure only increased to $3.4 \%$ between 2000 and 2015. According to the latest census, most of the foreign population living in the city came from Asian countries and, in particular, Chinese and Korean people account for about $60 \%$ of the foreign population. Because they tend to be employed as non-regular workers, who are usually paid less than regular workers, an increase in foreigners has the potential to affect social polarization in Tokyo in the future. While residential segregation of the foreign population is certainly confirmed in both the Region and the City (Kurasawa and Asakawa 2004; Wakabayashi and Koizumi 2018), this has only a limited influence on the overall levels of residential segregation because the absolute number of foreign residents is currently small.

The relatively limited correlation between income and occupational status may also be the reason that income inequality, occupational structure, and residential segregation are not strongly linked. One possible cause for this may be time lag effects. Tammaru et al. (2020) found that there is roughly a decade between inequality and segregation based on a comparative study of European cities. From a different point of view, Fujita and Hill (2012) proposed that Japan's compressed wage system is the primary reason income inequality does not translate into class-based residential segregation in Tokyo. Many companies in Japan still use a job evaluation-based wage system, which is partly because of the nature of the welfare system. It appears that as a consequence, disparities in income are more related to differences in the type of employment and seniority than differences between occupations. In fact, 
the weekly wages by occupations in Tokyo calculated according to the Employment Status Survey (Ministry of Internal Affairs and Communications) indicate that, while there is some correlation between occupation and income, the average wage of the highest occupational status (Administrative and managerial workers) is 3.0 times higher than that of the lowest occupational status (Production process and related workers) in 2012. This is still a modest difference compared to the European countries (Tammaru et al. 2016).

However, the above observations do not imply that occupational structures or residential segregation have not changed at all over 15 years. One particular cause of changes in residential segregation seems to be changed in land prices influenced by the overall socio-economic situation. The decline in land prices increased the supply of condominiums, which, in turn, helped in the recovery of population numbers in central Tokyo begin in the second half of the 1990s. By 2004, prices for residential land in the city had fallen to less than a third of what they were at the peak due to the economic bubble in 1992. Although the subsequent "mini-bubble" that took place in 2006-2008 somewhat helped prices recover by 2008, the financial crisis that struck that year pushed them down again, and the 2011 Great East Japan Earthquake ensured that prices continued to stagnate. In 2014, land prices began to climb as a result of the monetary easing that began in 2013. The level of residential segregation observed in the Region and the City has remained constant since the mid-2000s, which implies that the stagnation of the housing market and segregation is linked. While land prices increased in the center of the city and the bay area during the minibubble and resumed their climb after the monetary easing policy was implemented, in the surrounding areas real estate prices have continued to decline, with suburban condominium buildings constructed during the bubble era being severely affected (Hirayama 2017). Although Tokyo is located far away from the areas affected by the 2011 earthquake and tsunami, residents of the city have also become more safetyconscious, which has negatively affected land prices in low-lying eastern parts of the city that are vulnerable to disasters (Yamada 2015). It should be noted that although this study did not indicate the impact of the recovery period that came after 2014 if concentrated investment in "hot spots" recover along with the economy, residential segregation may once again become more pronounced.

Another important factor responsible for changes in residential segregation is residential preference. A survey among owners of new condominiums in the Tokyo region by Recruit Sumai Company Ltd. indicated that "walking time to the nearest station" is becoming an increasingly important factor for people planning to buy and rent houses: $75.5 \%$ rated it as important in 2005, which increased to $84.0 \%$ in 2010. This indicates that mainly high-income households, are choosing to live in highly convenient areas because such areas are relatively expensive. As the suburban population returns to the city center, suburban residential areas are also undergoing increasing selection and elimination as the overall demand for housing decreases.

Population decrease and declining birth rate in Japan will no doubt spur more changes in welfare and housing policies. For example, as the revised Immigration Control Act was approved at the end of 2018, the decline of the labor force has forced the Japanese government to open doors for low-skilled immigrants, a category 
that had hitherto not been admitted. Insufficient development of housing policies toward them remains another issue. As for urban policy, in 2014, the government revised the Act on Special Measures concerning Urban Reconstruction to realize compact cities suitable for the declining population. The Act gave each municipality the ability to designate specific areas where city functions and residential housing could be consolidated to encourage residents to move there. Such policies stimulate the selection and concentration of population in city centers, meaning they could accelerate residential segregation. In short, future trends in economic inequality and residential segregation in Tokyo will be an important topic of study.

\section{Notes}

1. Tokyo was not a direct disaster area, but the earthquake influenced the energy policy and real estate market nationwide.

2. This corresponds to the relationship between New York City and New York Metropolitan Area in the US as an example.

3. Neighborhoods with fewer than 50 workers are not reported.

Acknowledgements This research was supported by JSPS KAKENHI Grant Number JP17K13584.

\section{References}

Chiavacci D, Hommerich C (eds) (2017) Social inequality in post-growth Japan: transformation during economic and demographic stagnation. Routledge, New York

Duncan O, Duncan B (1955) Residential distribution and occupational stratification. Am J Sociol 60(5):493-503

Esping-Andersen G (1990) The three worlds of welfare capitalism. Polity Press, Cambridge

Fielding AJ (2004) Class and space: social segregation in Japanese cities. Trans Inst Br Geogr 29:64-84

Fujita K, Hill RC (2012) Residential income inequality in Tokyo and why it does not translate into class-based segregation. In: Maloutas T, Fujita K (eds) Residential segregation in comparative perspective: making sense of contextual diversity. Ashgate, Farnham, pp 54-86

Fujitsuka Y (2017) Jentorifikeshon [Gentrification]. Kokon Shoin, Tokyo

Hamnett C (1994) Social polarisation in global cities: theory and evidence. Urban Stud 31(3):401424

Hirayama Y (2005) Running hot and cold in the urban home-ownership market: the experience of Japan's major cities. J Hous Built Environ 20:1-20

Hirayama Y (2017) Selling the Tokyo sky: urban regeneration and luxury housing. In: Forrest R, Koh SY, Wissink B (eds) Cities and the super-rich: real estate, elite practices, and urban political economies. Palgrave MacMillan, London, pp 189-208

Hochstenbach C, Musterd S (2018) Gentrification and the suburbanization of poverty: changing urban geographies through boom and bust periods. Urban Geogr 39(1):26-53

Jacobs AJ (2005) Has central Tokyo experienced uneven development? an examination of Tokyo's $23 \mathrm{ku}$ relative to America's largest urban centers. J Urban Aff 27(5):521-555 
Jacobs AJ (2012) The nested global city-region: intermunicipal income stratification in the Tokyo metropolitan region, 1980-2007. Urban Geogr 33(1):120-146

Koizumi R, Wakabayashi Y (2015) Changes in the spatial patterns of occupational structure in the Tokyo metropolitan area after the bubble economy. In: Singh R (ed) Urban development challenges, risks and resilience in Asian mega cities. Springer, Tokyo, pp 351-366

Kurasawa S, Asakawa T (eds) (2004) Shinpen Tokyoken no shakai chizu, 1975-90 [New social atlas of metropolitan Tokyo, 1975-90]. University of Tokyo Press, Tokyo

Lützeler R (2008) Population increase and "new-build gentrification" in central Tokyo. Erdkunde 62:287-299

Marcińczak S, Tammaru T, Novak J, Gentile M, Kovács Z, Temelova J, Valatka V, Kährik A, Szabo B (2015) Patterns of socioeconomic segregation in the capital cities of fast-track reforming postsocialist countries. Ann Am Assoc Geogr 105:183-202

Machimura T (1994) Sekai toshi Tokyo no kouzou tenkan [The structural change of a global city: urban restructuring in Tokyo]. University of Tokyo Press, Tokyo

MHLW (2012) Annual health, labour and welfare report 2012. Ministry of Health, Labour and Welfare, Tokyo

MHLW (2013) Analysis of the labour economy 2013 (White paper on the labour economy 2013). Ministry of Health, Labour and Welfare, Tokyo

Ministry of Internal Affairs and Communications (2009) The history of the Japan standard occupational classification. http://www.soumu.go.jp/english/dgpp_ss/seido/shokgyou/co09-1. htm. Accessed 1 Mar 2019

Musterd S, van Gent W (2016) Changing welfare context and income segregation in Amsterdam and its metropolitan area, 2004-2011. In: Tammaru T, van Ham M, Marcińczak S, Musterd S (eds) Socio-economic segregation in European capital cities: east meets west. Routledge, London and New York, pp 55-79

OECD (2013) Definition of functional urban areas (FUA) for the OECD metropolitan database. https://www.oecd.org/cfe/regional-policy/Definition-of-Functional-Urban-Areas-forthe-OECD-metropolitan-database.pdf. Accessed 1 Mar 2019

OECD (2015) In it together: why less inequality benefits all. OECD Publishing, Paris

Ohtake F (2008) Inequality in Japan. Asian Econ Policy Rev 3:87-109

Sassen S (1991) The global city: New York, London. Princeton University Press, Princeton, Tokyo

Sawyer M (1976) Income distribution in OECD countries, OECD economic outlook. OECD, Paris

Shikata M (2013) Family structure, employment and income equality in Japan: decomposition analysis of age-specific income inequality. Q Soc Secur Res 49(3):326-338 (In Japanese)

Sonobe M (2001) Gendai daitoshi shakai ron: bunkyokuka suru toshi? [Contemporary metropolitan society: dual city?]. Toshindo Publishing, Tokyo

Tachibanaki T (2005) Confronting income inequality in Japan: a comparative analysis of causes, consequences and reform. MIT Press, Cambridge

Takagi K (2012) Toshi jutaku seisaku to shakai-kuukan kouzou [Urban housing policy and sociospatial structure: a case study of the Tokyo metropolitan area]. Yuhikaku, Tokyo

Tammaru T, van Ham M, Marcińczak S, Musterd S (eds) (2016) Socio-economic segregation in European capital cities: east meets west. Routledge, London and New York

Tammaru T, Marcińczak S, Aunap R, van Ham M, Janssen H (2020) Relationship between income inequality and residential segregation of socioeconomic groups. Reg Stud 54(4):450-461

Toyoda T (2007) Social polarization and socio-spatial structure of metropolitan areas: A comparative analysis of income inequality in Tokyo, Osaka and Nagoya. Ann Jpn Assoc Urban Sociol 25:5-21 (In Japanese)

Ueno J (2008) The impact of deregulation and urban development: socio-spatial polarization in Tokyo. Ann Jpn Assoc Urban Sociol 26:101-115 (In Japanese)

van Kempen R (2007) Divided cities in the 21st century: challenging the importance of globalization. J Hous Built Environ 22(1):13-31 
Wakabayashi Y, Koizumi R (2018) Spatial patterns of population change in central Tokyo since the period of the bubble economy. In: Kikuchi T, Sugai T (eds) Tokyo as a global city: new geographical perspectives. Springer, Singapore, pp 155-176

Waley P (2007) Tokyo-as-world-city: reassessing the role of capital and the state in urban restructuring. Urban Stud 44(8):1465-1490

Waley P (2013) Pencilling Tokyo into the map of neoliberal urbanism. Cities 32:43-50

Wissink B, Hazelzet A (2012) Social networks in "Neighbourhood Tokyo". Urban Stud 49(7):15271549

Yamada H (2015) Spatial characteristics of land evaluation in the Tokyo metropolitan area after the Great East Japan Earthquake. In: Hino M, Tsutsumi J (eds) Urban geography of post-growth society. Tohoku University Press, Sendai, pp 159-178

Yoshida A, Endo H (1999) Spatial distribution of per-capita income and occupations in the Tokyo metropolitan area. J Appl Reg Sci 4:15-25 (In Japanese)

Open Access This chapter is licensed under the terms of the Creative Commons Attribution 4.0 International License (http://creativecommons.org/licenses/by/4.0/), which permits use, sharing, adaptation, distribution and reproduction in any medium or format, as long as you give appropriate credit to the original author(s) and the source, provide a link to the Creative Commons license and indicate if changes were made.

The images or other third party material in this chapter are included in the chapter's Creative Commons license, unless indicated otherwise in a credit line to the material. If material is not included in the chapter's Creative Commons license and your intended use is not permitted by statutory regulation or exceeds the permitted use, you will need to obtain permission directly from the copyright holder. 